\title{
Performance Evaluation of Refractory Composite Coatings in Potassium Rich Environment
}

\author{
Kristina BRINKIENE் * , Jūratė ČĖSNIENĖ, Regina KALPOKAITE்-DIČKUVIENE், \\ Irena LUKOŠIŪTE்
}

Lithuanian Energy Institute, Breslaujos 3, LT-44403 Kaunas, Lithuania

cross $^{\text {ref }}$ http://dx.doi.org/10.5755/j01.ms.22.3.8348

Received 30 September 2014; accepted 25 December 2014

\begin{abstract}
A laboratory scale method was used to study the performance of reinforced cement composites in potassium rich environment of biomass combustion. Buckwheat husk (BH) was used as potential source of unexploited biomass product applicable as biomass derived fuel. In order to enhance the alkali effect on the properties of the investigated materials, the solution of potassium carbonate $\left(\mathrm{K}_{2} \mathrm{CO}_{3}\right)$ was selected as potassium rich aggressive environment. Two reinforced cement composites as potential repair coatings for restoration of damaged refractory surfaces with different composition of aggregate were used in corrosion tests. Performance of refractory coatings was evaluated by analysing the microstructure of the treated composites as well as mechanical properties. Energy-dispersive X-ray spectroscopy (SEM/EDS) and optical microscopy were used to study the microstructure in the corroded region of the refractory coatings. Long term studies in the solution of $1 \mathrm{M} \mathrm{K}_{2} \mathrm{CO}_{3}$ for 56 months have demonstrated that composite with the additive of fluid cracking catalyst of oil refinery and petrochemical industries is more durable in the potassium rich environment.
\end{abstract}

Keywords: refractory coatings, waste additives, environmental performance, potassium attack, microscopy.

\section{INTRODUCTION}

Refractory materials are widely used in various high temperature environments to insulate and protect internal linings of heat equipments [1-3]. Over the time, high temperature and chemically aggressive environment, even in presence of small amount of corrodients, may cause a damage of the lining.

With the growing concerns of greenhouse emissions, biomass becomes an important contributor to world energy needs [4]. Co-firing of fossil fuels with agro-biomass can significantly reduce $\mathrm{CO}_{2}$ emissions. The primary failure of the refractories used in biomass combustion devices occurs due to corrosion/erosion associated with biomass materials [2]. The failure mechanism is usually related to the chemical attack of alkalis (mainly sodium and potassium), which results in the weakening bonds, volumetric expansion and the degradation of refractory lining due to slag infiltration into the porous surface of refractory or by chemical dissolution of the slag into the refractory $[1,2]$. Analysis of various kinds of biomass fuels demonstrated higher amounts of alkalis [2]. According to [5, 6], calcium (Ca) and magnesium $(\mathrm{Mg})$ usually increase the ash melting point, while potassium $(\mathrm{K})$ decreases it. This causes sintering or slag formation as well as hard deposit formation on cooled furnace walls [5].

As an example of a new type of agro-industrial product, the buckwheat husk must be presented as an unexploited biomass product applicable for combustion and gasification [4,7]. According to [4], it is possible to use about 200-300 thousand tons of buckwheat husks as

\footnotetext{
${ }^{*}$ Corresponding author. Tel.: +370-37-401984; fax: +370-37-351271.

E-mail address: Kristina.Brinkiene@lei.lt (K. Brinkienè)
}

fuel annually. Buckwheat is rich in $\mathrm{K}, \mathrm{Mg}, \mathrm{Ca}$, and silica (Si) $[7,8]$. The ash obtained from buckwheat husk (calcination at $1000{ }^{\circ} \mathrm{C}$ ) contains a significant amount of $\mathrm{K}$ ions (up to $16 \mathrm{wt} . \%$ ), the content of $\mathrm{Mg}$ is approximately 10 wt. $\%, \mathrm{Ca}-1.5$ wt.\%, $\mathrm{Si}-$ up to 4 wt.\% [7]. Due to high potassium content, biomass ashes melt and sinter at lower temperatures therefore heavy deposits of biomass combustion formed on the wall of the furnace may cause the chemical corrosion of the wall material [8].

In order to determine the performance of alumina based refractories as possible repair coatings exploitable in the media of biomass combustion, the buckwheat husk biomass was chosen for this study as unexplored sort of biomass with quite different chemical composition than other widely studied types of biomass, such as wood, straw, rice straw and husk or sunflower husk [2, 4-6]. The silicon oxide is dominant constituent $(>50 \%)$ in the ash of these products. Buckwheat products are characterised by high content of potassium and their ash is high alkaline $[7,8]$. The combustion of this type of biomass might be associated with the formation of slag at higher degree and possible corrosion of contacted surfaces due to potassium alkali attack.

The objective of this work was to evaluate the performance of the selected alumina based refractory materials in high temperature alkali environment of buckwheat husk combustion. Whereas alkali corrosion test is long process, samples were supplementary exposed to the solution of potassium carbonate salt in order to enhance the alkali effect on the long term environmental stability of the composites. The hot corrosion processes by each corrosive agent were evaluated analysing the properties of the refractory composites and by the observation of X-ray elemental distributions in the corroded region. 


\section{EXPERIMENTAL}

\subsection{Materials}

Refractory composites were produced by mixing complex binder with fireclay aggregates. Main constituents of complex binder were the following: calcium alumina cement Gorkal 70 (CAC) (produced in Gorka Enterprise, Trzebinia, Poland) - main phases $\mathrm{CA}\left(\mathrm{CaO} \cdot \mathrm{Al}_{2} \mathrm{O}_{3}\right)$ and $\mathrm{CA}_{2}\left(\mathrm{CaO} \cdot 2 \mathrm{Al}_{2} \mathrm{O}_{3}\right)$; metallurgical slag (MS) (Chelyabinsk Electrometallurgic Plant, Russia) $-\gamma-2 \mathrm{CaO} \cdot \mathrm{SiO}_{2}$ content $\sim 85 \%$; and liquid glass solution (LG) (produced in enterprise Remesta, Lithuania) - silicate module of 3.3 $\left(\mathrm{SiO}_{2} / \mathrm{Na}_{2} \mathrm{O}\right)\left(\right.$ density $\left.1250 \mathrm{~kg} / \mathrm{m}^{3}\right)$. Microsilica $(\mathrm{mSi})$ in the form of ultra-disperse spheres of a size up to $150 \mathrm{~nm}$ (RW Silicium GmbH, Germany), monomodal reactive alumina (RA) CTC 20 (particle size $1.8 \mu \mathrm{m}$ ) (Almatis, Germany) and microfibre $(\mathrm{mF})$ were used as additives [9]. Microfibre was produced by plasma spray method [10] from the fluid cracking catalyst of oil refinery and petrochemical industries (FCC), which is famous for its zeolite structure. The fiber up to $5 \mathrm{~mm}$ in length and $5-10 \mu \mathrm{m}$ in diameter was added to the mixes as complex binder reinforcement. Microfibre was heat treated at $900{ }^{\circ} \mathrm{C}$ for $2 \mathrm{~h}$ to obtain the crystalline mullite phase before it was incorporated to the refractory composite. According to [11], the addition of microsilica (5-8wt.\%) increases the density and the mechanical strength of refractory concrete with complex binder, meanwhile $4 \%$ of microsilica reduces the thermal durability of the material. Deflocculant Castament FS-20 (BASF, Germany) was used for the formation of the mixes (0.15 wt.\%). Chemical composition of the raw materials collected from the data sheets supplied by the manufacturers and suppliers is presented in Table 1. Additional information can be found in the literature [12].

Table 1. Chemical composition (wt.\%) of raw materials provided by manufactures and suppliers

\begin{tabular}{|l|c|c|c|c|c|c|}
\hline \multicolumn{1}{|c|}{ Oxide } & CAC & $m S i$ & MS & RA & Fireclay & FCC \\
\hline $\mathrm{SiO}_{2}$ & 0.35 & 96.06 & 29.6 & 0.03 & $70-50$ & 50.1 \\
\hline $\mathrm{Al}_{2} \mathrm{O}_{3}$ & 70.50 & 0.20 & 4.33 & 99.70 & $25-45$ & 39.4 \\
\hline $\mathrm{Fe}_{2} \mathrm{O}_{3}$ & 0.10 & 0.05 & 1.34 & 0.03 & $0.5-3$ & 1.3 \\
\hline $\mathrm{CaO}$ & 28.7 & 0.25 & 54.3 & 0.02 & $0-1$ & 0.5 \\
\hline $\mathrm{MgO}$ & - & 0.40 & 6.7 & - & $0-1$ & 0.49 \\
\hline $\mathrm{K} 2 \mathrm{O}$ & - & 1.20 & - & - & $0-0.3$ & 0.07 \\
\hline $\mathrm{Na}_{2} \mathrm{O}$ & - & 0.10 & - & 0.12 & & 0.2 \\
\hline Other & 0.35 & 1.74 & 3.73 & 0.10 & - & 7.94 \\
\hline
\end{tabular}

In this study two refractory composites were formed using a complex binder and different admixtures of aggregate (Table 2). Multi-fractional aggregate of fireclay (FA) with particle size up to $1 \mathrm{~mm}$ (basic fraction $0.2 / 0.4 \mathrm{~mm}$ up to $52 \%$ ) was used as the main filler (composite R1). The composite R2 was prepared with the addition of fine-grained additive (average diameter of spherical particles $\sim 42 \mu \mathrm{m}$ ) of the fluid cracking catalyst waste (FCC), which behaves as active filler aggregate and reduces the effect of micro cracking [13]. Table 2 gives the compositions of the investigated mixes and water-to-solid ratio (w/s). Plasticity of composites determined according to LST EN 1402-4:2006 was 50-60\%.

Corrosion agents used for the investigations of the performance of refractory coatings in potassium rich environment were buckwheat husk from local production and chemically pure potassium carbonate (Sigma-Aldrich).

\subsection{Methods of investigation}

Ash residue of buckwheat husk was subjected to simultaneous differential scanning calorimetry and thermogravimetric analysis (DSC/TG) carried out on a Netzsch instrument STA 409 PC in nitrogen atmosphere with the heating rate $15 \mathrm{~K} / \mathrm{min}$. X-ray diffraction (XRD) patterns were obtained on Bruker Discovery diffractometer using $\mathrm{Cu}-\mathrm{K} \alpha$ radiation source. The existing phases were identified by the commercial Crystalographica SearchMatch ${ }^{\circledR}$ software.

Samples of dimensions of $(20 \times 20 \times 20) \mathrm{mm}$ were formed and cured for 3 days at the humidity of $(95 \pm 5) \%$ and 4 days at the ambient temperature of $(20 \pm 2){ }^{\circ} \mathrm{C}$. After curing the samples were dried at $100{ }^{\circ} \mathrm{C}$ until they reached constant weight. Each group of samples were exposed to $1000{ }^{\circ} \mathrm{C}$ for $12 \mathrm{~h}$ and cooled to room temperature before the testing in potassium rich environment.

Corrosion resistance of refractory composites was analysed in the alkali environment of buckwheat husk combustion. The investigated specimens were placed in the crucible, abundantly covered with buckwheat husk and exposed to $800{ }^{\circ} \mathrm{C}$ for $3 \mathrm{~h}$ daily. Heating/cooling rate was $100{ }^{\circ} \mathrm{C}$ per $30 \mathrm{~min}$. Test duration 30 cycles (Table 3 ).

Long-term attack of potassium alkaline environment on the refractory composites was carried out in the solution of potassium carbonate $\left(1 \mathrm{M} \mathrm{K}_{2} \mathrm{CO}_{3}\right)$ (Table 3$)$ by the immersion technique. The solution with the specimens was kept at room temperature and stirred regularly. The solution was replaced weekly to maintain the concentration of the solution stable throughout the test period. After the defined period of time the samples were removed from the solution, dried and exposed to the treatment at $800{ }^{\circ} \mathrm{C}$.

The affected cross-sectional surfaces of the composites were analysed using optical microscope Olympus BX51TF with QCapture®Pro software as well as scanning electron microscopy (Zeiss EVO MA10) equipped with XFlash®6I10 detector for EDS analysis using QUANTAX®Espirit software. Resolution of the scan area was $1000 \times 750$ pixels. In order to study the K penetration into the composites during the alkali treatment, SEM images were recorded and several places along the corroded layer were chosen to analyse the chemical composition with SEM/EDS.

Table 2. Mix composition of studied refractory composites (wt.\%)

\begin{tabular}{|c|c|c|c|c|c|c|c|c|c|c|}
\hline \multirow{2}{*}{ Composition } & \multicolumn{3}{|c|}{ Complex binder } & \multirow{2}{*}{$\begin{array}{c}\text { Binder/ } \\
\text { Aggregate }\end{array}$} & \multirow{2}{*}{ Fiber* } & \multirow{2}{*}{$\mathrm{mSi}^{*}$} & \multirow{2}{*}{$\mathrm{RA}^{*}$} & \multicolumn{2}{|c|}{ Aggregate composition } & \multirow{2}{*}{$\mathrm{w} / \mathrm{s}$} \\
\hline & $\overline{\mathrm{CAC}}$ & MS & $\overline{L G}$ & & & & & FA & FCC & \\
\hline $\mathrm{R} 1$ & 51 & 17 & 32 & $1 / 1$ & 3 & 4 & 4 & 50 & - & 0.27 \\
\hline $\mathrm{R} 2$ & 51 & 17 & 32 & $1 / 1$ & 3 & 4 & 4 & 35 & 15 & 0.28 \\
\hline
\end{tabular}


The selected places were taken at the distance of 0.5 and $1.5 \mathrm{~mm}$ from the contact zone and at each depth, the elemental analysis was recorded at five places. EDS analysis was performed on polished samples non-mounted into epoxy resin. The affected samples were investigated by analysing the microstructure of the contact zone, chemical composition and the presence of cracks in the impact zone.

Table 3. Experimental conditions

\begin{tabular}{|c|c|c|c|c|}
\hline \multirow{2}{*}{ Test No } & \multicolumn{2}{|c|}{ Corrosion test } & \multicolumn{2}{c|}{ Firing } \\
\cline { 2 - 5 } & $\begin{array}{c}\text { Potassium } \\
\text { corrodient }\end{array}$ & $\begin{array}{c}\text { Exposure } \\
\text { time }\end{array}$ & $\mathrm{T},{ }^{\circ} \mathrm{C}$ & $\begin{array}{c}\text { Duration, } \\
\mathrm{h}\end{array}$ \\
\hline 0 & - & - & 1000 & 12 \\
\hline 1 & $\mathrm{BH}$ & 30 cycles & 800 & 3 \\
\hline 2 & $1 \mathrm{M} \mathrm{K}_{2} \mathrm{CO}_{3}$ & 30 days & 800 & 3 \\
\hline 3 & $1 \mathrm{M} \mathrm{K}_{2} \mathrm{CO}_{3}$ & 56 months & 800 & 3 \\
\hline
\end{tabular}

Bulk density and open porosity of the composites were determined according to LST EN 772-4:2000 using distilled water as the immersion liquid. Before the test the samples were dried at $(100 \pm 5){ }^{\circ} \mathrm{C}$. The immersed mass and the wet mass were measured after $48 \mathrm{~h}$ immersion in water at room temperature $\left(22^{\circ} \mathrm{C}\right)$.

Adhesion strength of the refractory coatings was measured by adhesion tester Elcometer 1940 Pat GM01 $(6.3 \mathrm{kN})$ using pull off disc of diameter $20 \mathrm{~mm}$.

For adhesion test the refractory samples of both compositions with dimensions of $(50 \times 100) \mathrm{mm}$ and $2 \mathrm{~mm}$ in thickness were formed on the substrate of refractory concrete according to LST EN 1015-12:2002/P:2004. Before making the coating, the substrates were wellirrigated with water. The formed coatings were cured for 3 days at above the water and for 4 days at the ambient temperature of $(20 \pm 2){ }^{\circ} \mathrm{C}$. After curing all samples were dried at $(100 \pm 2){ }^{\circ} \mathrm{C}$ until they reached constant weight and fired at $800{ }^{\circ} \mathrm{C}$ for $3 \mathrm{~h}$. Adhesion strength of coatings was also evaluated after the test in $\mathrm{BH}$.

Compressive strength was determined according to EN ISO 8895:2006. Tests were performed on 5 specimens for each group using Zwick Roell universal test machine of the capacity up to $50 \mathrm{kN}$.

The ability of the materials to withstand high temperature environmental conditions was investigated by a thermal cycling test. The samples were heated up to $1000{ }^{\circ} \mathrm{C}$ in the furnace at $9^{\circ} \mathrm{C} / \mathrm{min}$ and after $3 \mathrm{~h}$ of exposure at this temperature the samples were cooled up to room temperature at the same rate. This procedure was repeated up to 10 cycles. The damage that occurs during the thermo cycling was analysed by an optical microscope.

\section{RESULTS AND DISCUSION}

\subsection{Investigation of the buckwheat husk}

The profiles of DSC/TG analysis are presented in Fig. 1. The termogravimetric curve (TG) presents the first event of the thermal decomposition in the temperature interval of $25-180{ }^{\circ} \mathrm{C}$, which corresponds to the dehydration of the material (mass change $8.73 \%$ ). At temperature ranges of $180-280,280-360,360-430$ and $430-900{ }^{\circ} \mathrm{C}$ total weight loss is $67.73 \%$ and it corresponds to a complex of processes such as dehydration, depolymerisation and pyrolysis of volatile substances and their thermal decomposition [14]. During the combustion of biomass, large amounts of volatile alkali metals such as $\mathrm{K}$ are released mainly as vapours which may condense in the form of small particles of fly ash and have impact on the surrounding wall surfaces [5]. Total weight loss on TG curve of decomposition of $\mathrm{BH}$ at $900{ }^{\circ} \mathrm{C}$ is $76.46 \%$ while the mass of the ash residue is $23.54 \%$.

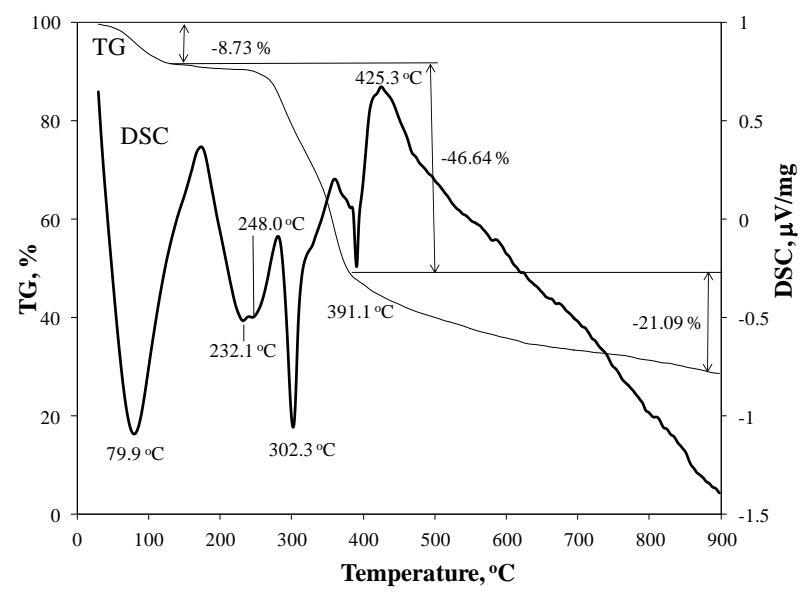

Fig. 1. TG and DSC curves of the buckwheat husk

$\mathrm{X}$-ray diffraction analysis of the buckwheat husk fired at $800{ }^{\circ} \mathrm{C}$ for 1 and $3 \mathrm{~h}$ was performed and XRD patterns of $\mathrm{BH}$ ash are presented in Fig. 2.

According to XRD data, the obtained ash is in crystalline state (Fig. 2), where the sharp peaks of potassium, calcium and magnesium compounds are prominent in the XRD patterns.

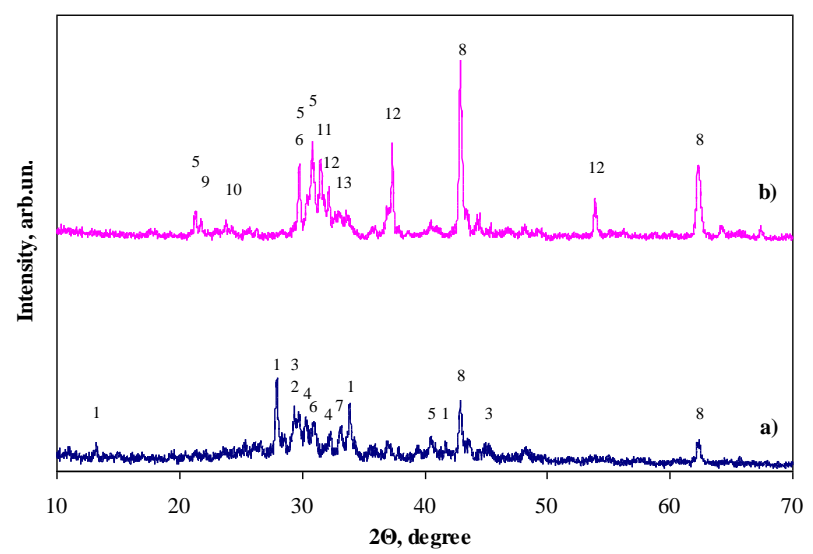

Fig. 2. XRD patterns of ash residue of buckwheat husk fired at $800{ }^{\circ} \mathrm{C}$ temperature for $\mathrm{a}-1 \mathrm{~h}$ and $\mathrm{b}-3 \mathrm{~h}$ : $1-\mathrm{K}_{2} \mathrm{Ca}\left(\mathrm{CO}_{3}\right)_{2} ; 2-\mathrm{SiO}_{2}$ (coesite); $3-\mathrm{CaCO}_{3}$ (calcite); $4-\mathrm{KCaPO}_{4} ; \quad 5-\mathrm{K}_{2} \mathrm{SO}_{4} ; \quad 6-\mathrm{SiO}_{2} \quad$ (silicon oxide); $7-\mathrm{Ca}_{3} \mathrm{Al}_{2} \mathrm{O}_{6}$ (calcium aluminium oxide); 8- $\mathrm{MgO}$; $9-\mathrm{SiO}_{2}$ (cristobalite low temperature); $10-\mathrm{CaMn}\left(\mathrm{CO}_{3}\right)_{2}$; $11-\mathrm{Na}_{2} \mathrm{SO}_{4}$ (aphthitalite); $12-\mathrm{CaO} ; 12-\mathrm{K}_{2} \mathrm{CO}_{3}$

XRD data obtained coincide with [7], wherein it was stated that potassium in the ash of buckwheat husk may exist as oxides or carbonates that exhibit high alkalinity in solution. Analysis of aqueous extract of the investigated $\mathrm{BH}$ ash pointed high alkaline $\mathrm{pH}$ (11). The data of chemical analysis indicated that ash is rich in potassium $\left(\mathrm{K}_{2} \mathrm{O} 31.7 \%\right)$, magnesium $(\mathrm{MgO} 21.5 \%)$ and calcium 
$(\mathrm{CaO} 19.5 \%)$. The silica content in $\mathrm{BH}$ ash is $0.8 \%$, alumina $-0.7 \%$, manganese oxide $0.6 \%$. The other part $(25.2 \%)$ is phosphorus, carbon and sulphur in the form of oxides.

\subsection{Investigation of the durability of refractory composites in potassium rich environments}

Typical SEM micrographs with corresponding areas used for EDS analysis and elemental spectra of as produced composites are presented in Fig. 3. The fine rounded shape FCC particle incorporated in the matrix of $\mathrm{R} 2$ is visible in the SEM micrograph (Fig. 3 b). Analysis of EDS spectra of untreated refractory composites revealed that $\mathrm{Al}, \mathrm{Si}, \mathrm{O}$ and $\mathrm{Ca}$ are the main elements of studied materials (Fig. 3, Table 4). Potassium concentration is low and varies in the range of $0.25-0.29$ (wt.\%).

After the treatment in buckwheat husk combustion environment, the increment of the potassium concentration up to $79 \%$ and $84 \%$ was found for the samples R1 and R2 at the distance of $0.5 \mathrm{~mm}$ from contact zone in comparison to the untreated control samples (Table 4). At the depth of $1.5 \mathrm{~mm}$ this increment was about $10 \%$ and $16 \%$ for the samples R1and R2, respectively.

Chemical composition (norm. wt.\%) of refractory composites exposed to potassium rich alkali environments for periods of 30 days (test 2) and for 56 month (test 3 ) are presented in Table 4.
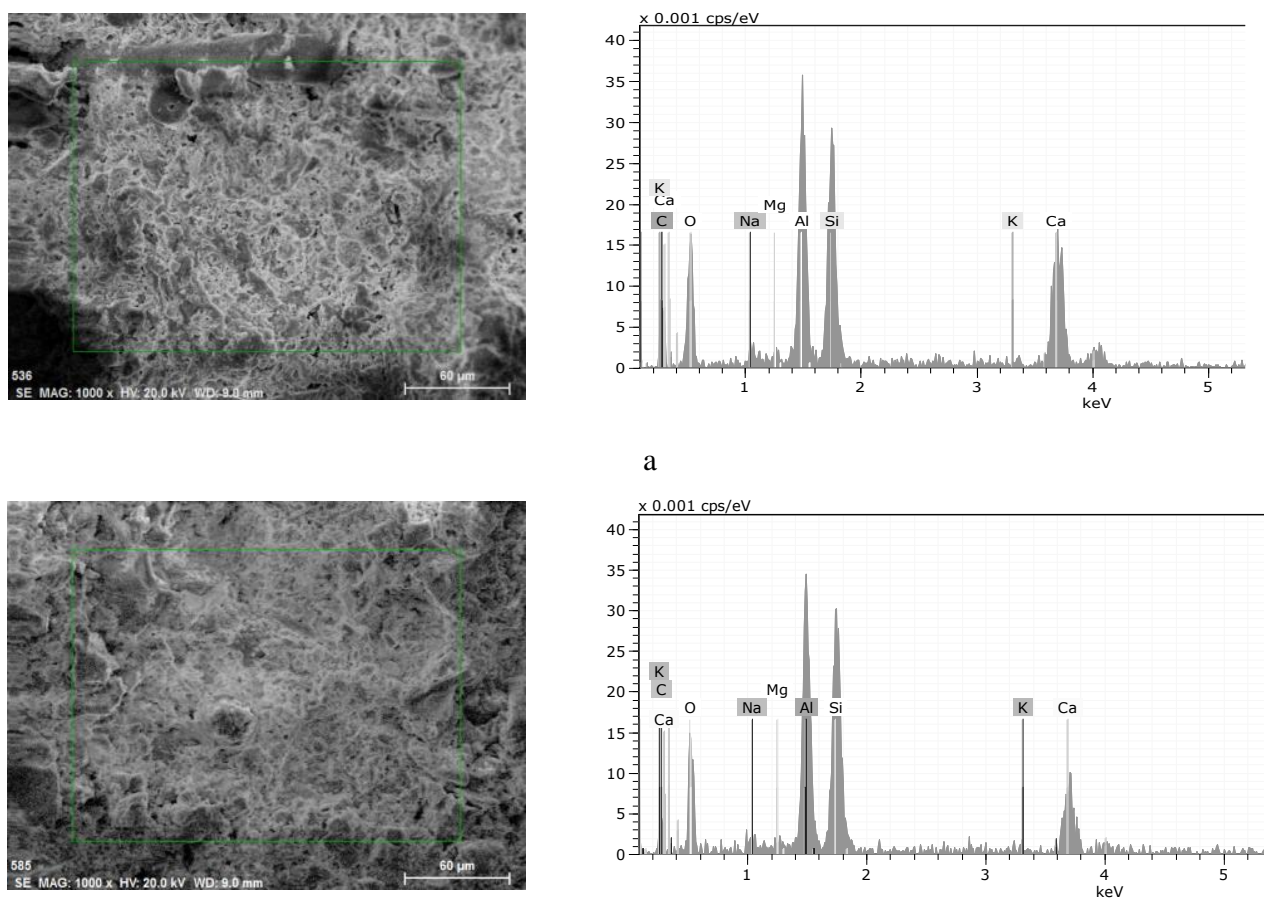

b

Fig. 3. SEM micrographs (left) and EDS spectra (right) of as produced composites fired at $1000{ }^{\circ} \mathrm{C}$ for $12 \mathrm{~h}$ : $\mathrm{a}-\mathrm{R} 1 ; \mathrm{b}-\mathrm{R} 2$

Table 4. Chemical composition (norm. wt \%) of refractory composites exposed to potassium alkali environments

\begin{tabular}{|c|c|c|c|c|c|c|c|c|}
\hline \multirow{3}{*}{$\begin{array}{l}\text { Element } \\
\text { K-series }\end{array}$} & \multicolumn{2}{|c|}{$\begin{array}{l}\text { Untreated } \\
\text { composites }\end{array}$} & \multicolumn{2}{|c|}{$\begin{array}{c}\text { Buckwheat husk } \\
\text { (test 1) }\end{array}$} & \multicolumn{2}{|c|}{$\begin{array}{c}1 \mathrm{M} \mathrm{K}_{2} \mathrm{CO}_{3} \\
\text { (test 2) }\end{array}$} & \multicolumn{2}{|c|}{$\begin{array}{c}1 \mathrm{M} \mathrm{K}_{2} \mathrm{CO}_{3} \\
\text { (test 3) }\end{array}$} \\
\hline & \multirow{2}{*}{ R1 } & \multirow{2}{*}{ R2 } & $\mathrm{R} 1$ & $\mathrm{R} 2$ & $\mathrm{R} 1$ & $\mathrm{R} 2$ & $\mathrm{R} 1$ & $\mathrm{R} 2$ \\
\hline & & & \multicolumn{6}{|c|}{ Depth $0.5 \mathrm{~mm}$} \\
\hline $\mathrm{O}$ & 47.38 & 48.84 & 43.58 & 44.62 & 55.07 & 47.67 & 53.61 & 54.19 \\
\hline $\mathrm{Na}$ & 2.54 & 1.36 & 2.34 & 2.27 & 1.15 & 1.78 & 1.58 & 1.88 \\
\hline $\mathrm{Mg}$ & 0.95 & 1.29 & 0.68 & 0.67 & 0.58 & 0.77 & 1.17 & 0.62 \\
\hline $\mathrm{Al}$ & 20.79 & 17.66 & 20.98 & 18.55 & 15.22 & 18.67 & 15.83 & 17.58 \\
\hline $\mathrm{Si}$ & 18.64 & 15.85 & 17.58 & 18.84 & 14.60 & 14.51 & 10.11 & 11.77 \\
\hline $\mathrm{K}$ & 0.29 & 0.25 & 0.52 & 0.46 & 0.61 & 0.55 & 1.77 & 1.71 \\
\hline $\mathrm{Ca}$ & 9.51 & 14.75 & 14.32 & 14.59 & 12.67 & 16.12 & 15.93 & 12.25 \\
\hline & & & \multicolumn{6}{|c|}{ Depth $1.5 \mathrm{~mm}$} \\
\hline $\mathrm{O}$ & 47.38 & 48.84 & 44.83 & 48.55 & 50.13 & 47.91 & 47.27 & 43.81 \\
\hline $\mathrm{Na}$ & 2.54 & 1.36 & 1.07 & 1.21 & 1.74 & 2.08 & 1.80 & 1.82 \\
\hline $\mathrm{Mg}$ & 0.95 & 1.29 & 0.83 & 0.79 & 0.73 & 0.94 & 1.06 & 0.85 \\
\hline $\mathrm{Al}$ & 20.79 & 17.66 & 20.93 & 17.58 & 18.61 & 16.92 & 16.28 & 16.76 \\
\hline $\mathrm{Si}$ & 18.64 & 15.85 & 18.68 & 16.92 & 15.13 & 16.18 & 15.93 & 19.90 \\
\hline $\mathrm{K}$ & 0.29 & 0.25 & 0.32 & 0.29 & 0.44 & 0.39 & 1.30 & 1.15 \\
\hline $\mathrm{Si}$ & 9.51 & 14.75 & 13.34 & 14.66 & 13.22 & 15.58 & 16.36 & 15.71 \\
\hline
\end{tabular}


Results of quantitative X-ray microanalysis showed approximately two times higher concentration of potassium for the samples after treatment in the potassium carbonate solution during test 2. At the depth of $0.5 \mathrm{~mm}$ from contact zone up to 17-20\% higher concentration of potassium was detected for R1 and R2, respectively, than after the test in $\mathrm{BH}$ combustion environment. At the depth of $1.5 \mathrm{~mm}$ the concentration of $\mathrm{K}$ increased up to $52-$ $56 \%$ for samples exposed to test 2 conditions in comparison with the untreated composites. After long-term treatment (56 months) in the solution of $1 \mathrm{M} \mathrm{K}_{2} \mathrm{CO}_{3}$ (test 3) the concentration of $\mathrm{K}$ increased up to values $1.71-$ $1.77 \mathrm{wt} . \%$ at the depth of $0.5 \mathrm{~mm}$ from contact zone and up to $1.15-1.30 \mathrm{wt} . \%$ at the distance of $1.5 \mathrm{~mm}$ (Table 4) that was more than four times higher than initial concentration of $\mathrm{K}$ of untreated samples.

Comparative study of SEM/EDS maps of the samples for $\mathrm{Si}, \mathrm{Al}, \mathrm{Mg}, \mathrm{Ca}, \mathrm{Na}, \mathrm{K}$ and $\mathrm{O}$ showed homogeneous distribution of the selected elements in the bulk of nontreated composites as well as for the samples tested in $\mathrm{BH}$ and in the solutions of potassium carbonate. The elemental distribution showed similar results for both groups of composites R1 and R2. Fig. 4 gives the visual representation of potassium distributions in the microstructures of tested samples. Higher concentration of potassium was observable in the $\mathrm{K}-\mathrm{K}$ maps of the samples treated in the solutions of $\mathrm{K}_{2} \mathrm{CO}_{3}$ (Fig. 4).

No segregation or any precipitation along the grain boundaries was noticed in the mapping images of $\mathrm{K}$. Exposure of refractories to the investigated environments revealed the penetration of potassium into the matrix. Quite a homogeneous distribution of potassium was found from the K-K maps of all studied samples.

Extended studies of the degradation mechanisms by slag and the alkalis in the refractory linings for iron ore pellet production showed [15] that the vaporised potassium penetrates through the voids and fissures, condenses and diffuses through the bulk and finally reacts with the lining material, consequently physical properties of the composites were investigated to clarify the physical performance of the materials affected by the corrosion treatment. The results of bulk density and open porosity
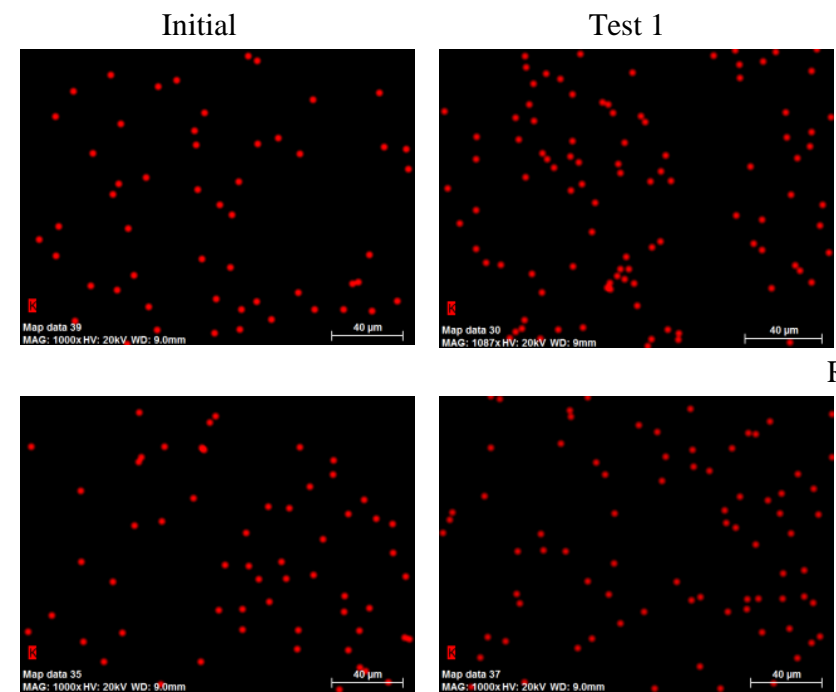

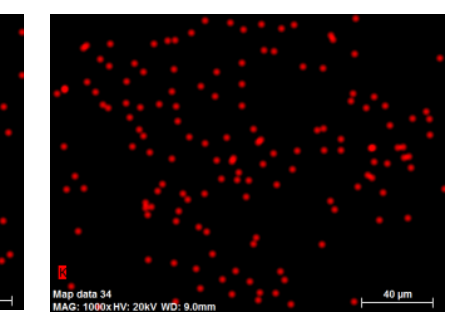

Test 2

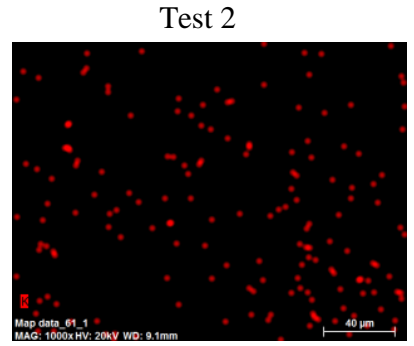

1

$\mathrm{R} 2$ before and after the alkaline treatments are presented in Table 5. After the treatment in $\mathrm{BH}$, no significant changes in the bulk density and the porosity of the composites R2 were found. The marginal decrease in the density up to $\sim 2 \%$ and the increase in the porosity up to $5 \%$ were established for R1 after the test 1 .

No substantial effect on the physical properties of the materials was observed after the exposure in the solution of $1 \mathrm{M} \mathrm{K}_{2} \mathrm{CO}_{3}$ for 30 days (test 2). Slight decrease up to $1.7 \%$ in the density of R1 with the increased porosity up to $2.6 \%$ or a minor increase of the density up to $1.2 \%$ with the increase in the open porosity up to $3.2 \%$ for sample R2 might be related with the hydration of the materials and the geometrical arrangement of the hydrated phases [16].

Long-lasting test (test 3 ) revealed an observable decrease up to $3.9 \%$ in the density with the marked increase in the porosity up to $8.1 \%$ for the sample R1. This might be related to the formation of microcracks during the treatment. The density of composite R2 remained practically unchanged after this treatment (decrease in density was $0.6 \%$ ), whereas the moderate increase in the porosity up to $4.0 \%$ was obtained.

Optical microscopy studies were carried out after thermal cycling on samples exposed to potassium attack. As shown in Fig. 5 thermal theatment in $\mathrm{BH}$ does not result in the formation of microcracks (Fig. 5, left), but after exposure to the corrosion test 2 a fine microcracking is visible in the optical image of the composite R1 (Fig. 5, centre). The average width of a crack is $\sim 15 \mu \mathrm{m}$. Higher degree of microcracking was found for composite R1 after the test 3 (Fig. 5, right). No microcracks were observed in the structure of the sample R2 after the treatment in potassium rich environments. It should be assumed that partial replacement of fireclay by waste catalyst (FCC) reduced the effect of microcracking.

Experimental studies showed that refractory coatings were sufficiently adhered to the refractory concrete. Table 6 shows the adhesive strength of the studied coatings after the firing at $1000{ }^{\circ} \mathrm{C}$ for $12 \mathrm{~h}$. The highest value of the adhesive strength (2.0 MPa) was determined for R2 composite with the addition of $15 \%$ of FCC to aggregate.
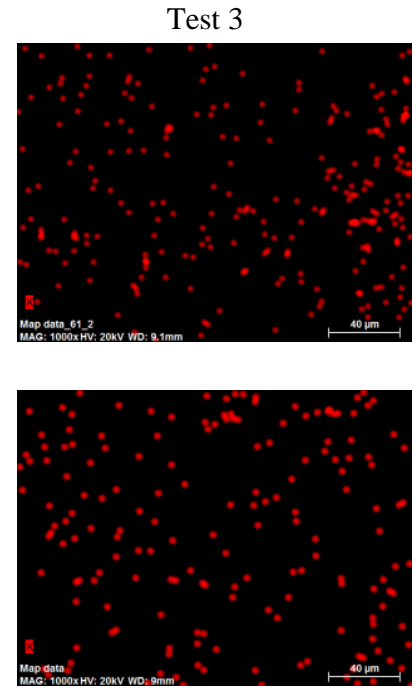

Fig. 4. SEM/EDS X-ray maps of potassium of investigated refractory composites R1 and R2 
Table 5. Bulk density and open porosity of composites tested in various environments

\begin{tabular}{|c|c|c|c|c|c|c|c|c|}
\hline \multirow{2}{*}{ Composite } & \multicolumn{4}{|c|}{ Bulk density, $\mathrm{kg} / \mathrm{m}^{3}$} & \multicolumn{4}{c|}{ Open porosity, \% } \\
\cline { 2 - 9 } & Initial & Test 1 & Test 2 & Test 3 & Initial & Test 1 & Test 2 & Test 3 \\
\hline R1 & $1780 \pm 9$ & $1740 \pm 6$ & $1750 \pm 8$ & $1710 \pm 7$ & 34.99 & 36.74 & 35.89 & 37.82 \\
\hline R2 & $1690 \pm 2$ & $1690 \pm 4$ & $1710 \pm 4$ & $1680 \pm 5$ & 35.70 & 35.83 & 36.84 & 37.14 \\
\hline
\end{tabular}

R1

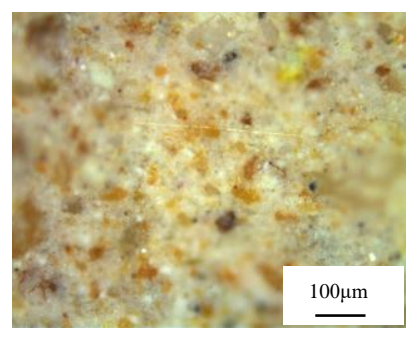

Test 1

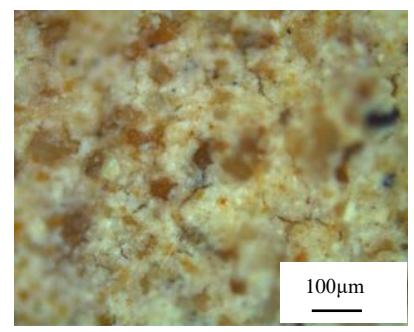

Test 2

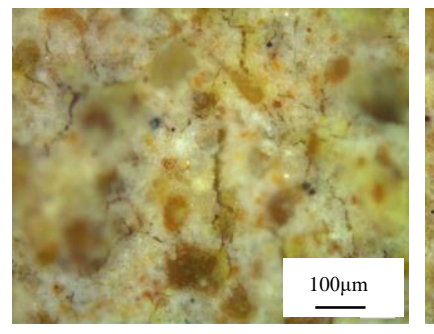

Test 3

Fig. 5. Optical images of tested refractory composites R1 and R2

Table 6. Strength (MPa) of tested refractories R1 and R2

\begin{tabular}{|c|c|c|}
\hline \multirow{2}{*}{ Strength } & \multicolumn{2}{|c|}{ Composites } \\
\cline { 2 - 3 } & $\mathrm{R} 1$ & $\mathrm{R} 2$ \\
\hline \multirow{2}{*}{ Adhesion strength } & $1.8 \pm 0.24$ & $2.0 \pm 0.24$ \\
\cline { 2 - 3 } & $1.7 \pm 0.24^{*}$ & $1.9 \pm 0.24^{*}$ \\
\hline \multirow{2}{*}{ Compression strength } & $48.5 \pm 1.7$ & $46.1 \pm 1.7$ \\
\cline { 2 - 3 } & $44.8 \pm 1.7^{*}$ & $44.2 \pm 1.7^{*}$ \\
\hline * After 30 cycles of firing in buckwheat husk at $800^{\circ} \mathrm{C}$ for $3 \mathrm{~h}$ \\
\hline
\end{tabular}

The treatment of composites in $\mathrm{BH}$ combustion environment marginally diminished the values of adhesion strength. Strength reduction up to $5.5 \%$ was found for sample R1, whereas $5.0 \%$ for R2, respectively (Table 6). Slightly higher value of compressive strength up to $\sim 5 \%$ was found for untreated refractory composite R1. After the treatment in corrosive environment of $\mathrm{BH}$, compressive strength diminished up to $7.6 \%$ for R1 and up to $4.1 \%$ for $\mathrm{R} 2$. Thus, the use of the inert material as a fine filler to aggregate can lead to an improvement in the particle packing by the proper arrangement of small particles to make the material denser [15] and to an improvement in the strength properties. It can be seen that the developed refractory composites exhibited high operational properties in the potassium rich environments of biomass combustion.

\section{CONCLUSIONS}

Two types of reinforced cement composites as potential repair coatings for the restoration of damaged refractory surfaces were studied in the potassium rich environment of buckwheat husk combustion $\left(800^{\circ} \mathrm{C}\right)$. Long-term attack of the potassium alkaline environment was carried out in the solution of potassium carbonate $\left(1 \mathrm{M} \mathrm{K}_{2} \mathrm{CO}_{3}\right)$ for 56 months. Performance of refractory coatings was evaluated by analysing the microstructure of the treated composites as well as mechanical properties.

SEM/EDS results showed that potassium penetrates into the structure of the refractories during treatment but does not cause significant changes in the microstructure and mechanical properties of the composites.

This study demonstrates that the addition of the fine filler FCC improves the durability of the studied refractory composites to withstand the potassium rich environmental conditions $\left(800{ }^{\circ} \mathrm{C}\right)$ and might be exploited as repair coatings for refractory linings.

\section{REFERENCES}

1. Bennett, J. P., Kwong, K. S. Refractory Liner Materials Used in Slagging Gasifiers Refractories applications and news 9 (5) 2004: pp. 20-25.

2. Rou, A. W. CFB Refractory Improvements for Biomass CoFiring. http://www.power-eng.com/articles/print/volume114/issue-7/Features/cfb-refractory-improvements-forbiomass-co-firing.html.

3. Pundiene, I., Goberis, S., Antonovich, V., Stonys, R., Spokauskas, A. Carbonation of Alumina Cement-bonded Conventional Refractory Castable in Fireplace Materials Science (Medžiagotyra) 12 (4) 2006: pp. 333-337.

4. Isemin, R. et al. Development of Technology of Slagless Combustion of Agricultural Wastes (Straw) and Designing and Manufacturing of Boilers Where this Technology is Applied Journal of the Japan Institute of Energy 90 2011: pp. 569-572.

5. Riedl, R., Dahl, J., Obernberger, I., Narodoslawsky, M. Corrosion in Fire Tube Boilers of Biomass Combustion Plants Proceedings. of the China International Corrosion control conference, Beijing, China, 1999: Paper Nr. 90129.

6. Li, N., Hupa, L., Yrjas, P., Hupa, M. Laboratory Study of Corrosion of an Alumina Refractory by Molten Potassium Salts Advances in Science and Technology 70 2010: pp. $65-71$.

7. Zemnuchova, L. A., Shorina, E. D., Fedorishcheva, G. A. Composition of Inorganic Components of Buckwheat Husk and Straw Russian Journal of Applied Chemistry 78 (2) 2005: pp. $324-328$. 
8. Khan, F. et al. Nutritional Evaluation of Common Buckwheat of Four Different Villages of Gilgit-Baltistan Journal of Agricultural and Biological Science 8 (3) 2013: pp. 264-266.

9. Kalpokaitè-Dičkuvienė, R., Brinkienè, K., Čèsnienė, J., Makštys, A. Effect of Fibre and Microsilica Incorporation on High temperature Resistance of Cementitious Complex Binder Materials Science (Medžiagotyra) 17 (1) 2011: pp. $69-72$.

10. Milieška, M. et al. Application of Plasma Technology for Nanofiber Formation from Oil Refinery Waste (Zeolite) Energetika 54 (4) 2008: pp. 54-58.

11. Goberis, S., Pundienè, I., Špokauskas, A., Wala, T. Microsilica Tested as a Component for the Binder of a Medium-Cement Refractory Castable Refractories and Industrial Ceramics 44 (4) 2003: pp. 205-210. http://dx.doi.org/10.1023/A:1027319112575

12. Kalpokaitė-Dičkuvienè, R. et al. V. Effect of Modifying Additives on Mechanical Properties of Refractory Concrete Materials Science (Medžiagotyra) 18 (3) 2012: pp. 290-295.
13. Žvironaitè, J., Pundienė, I., Antonovič, V., Balkevičius, V. Investigation of Peculiarities in the Hardening Process of Portland Cements with Active Additives out of Waste Materials Science (Medžiagotyra) 17 (1) 2011: pp. $73-79$.

14. Amorim, J. A. et al. Thermal Analysis of the Rice and byProducts Journal of Thermal Analysis and Calorimetry 75 2004: pp. 393-399. http://dx.doi.org/10.1023/B:JTAN.0000027125.77040.43

15. Stjernberg, J. et al. Extended Studies of Degradation Mechanisms in the Refractory Lining of a Rotary Kiln for Iron Ore Pellet Production Journal of the European Ceramic Society 32 2012: pp. 1519-1528. http://dx.doi.org/10.1016/j.jeurceramsoc.2012.01.012

16. Al-Salami, A. E. The Effect of Fly Ash on Resistance of Hardened Cement Pastes to Sodium Chloride Attack Journal of Applied Sciences 12 (1) 2012: pp. 84-89. DOI: $10.3923 /$ jas.2012.84.89.

http://dx.doi.org/10.3923/jas.2012.84.89 